\title{
Pain treatment in neonates - a Polish multicentre survey conducted in 2014
}

\author{
Magdalena M. Panek¹, Przemko Kwinta² \\ 'Department of Mother and Child Health, Institute of Nursing and Midwifery, Jagiellonian University Medical College, \\ Krakow, Poland \\ ${ }^{2}$ Children's Disease Clinic, Department of Paediatrics, Jagiellonian University Medical College, Krakow, Poland
}

\section{ABSTRACT}

Introduction: Preventing pain before and during medical procedures is a basic human right, regardless of age. Painful invasive procedures are frequently performed on infants admitted to neonatal units.

Aim of the study: The aim of this study was to describe current neonatal pain management in Polish neonatal units according to the opinions of physicians.

Material and methods: A survey of 100 Polish neonatal units was performed. Physicians were asked to complete a researcher-developed questionnaire. The survey comprised 40 questions. The frequency of use of selected pain medicines and pain treatment according to guidelines was assessed using Likert-scale questions. Results: Seventy-six units agreed to participate in the study. Data were available from 235 physicians. Most neonatal units did not have guidelines for the treatment of pain in newborns. There was no significant correlation between theoretical knowledge and pain treatment in accordance with the guidelines $(r=-0.04$, $p=0.6$ ). Pain treatment before selected procedures seems to be insufficient. The study revealed the frequent use of paracetamol before painful procedures. Before central line insertion $42 \%$ of physicians from level III units very often or often administered paracetamol. About $40 \%$ of physicians used paracetamol before chest tube insertion. Phenobarbital intravenous/per os/per rectum was the most frequently used drug ( $76 \%$ of respondents from level III NICU). Almost $60 \%$ of physicians did not use written guidelines for pain management, but they followed their experience.

Conclusions: Despite changes in the approach to pain management in neonates and the widespread availability of recommendations, pain treatment in Polish neonatal units is still insufficient. There is a need for the education of health professionals on neonatal pain management. This study suggests that Polish neonatal units need national guidelines for pain management.

KEY WORDS:

analgesia, neonates, procedural pain.

\section{INTRODUCTION}

Relieving pain and suffering is one of the main tasks of modern medicine, but coping with this need in neonatal units can be a big challenge. There are many difficulties associated with pain treatment in this group of patients. One of them is the immature nervous system of newborns and their different response to painful stimuli. Another concern is doctors' fears about the side effects of pain medications that cause them to give up their use, expos-

\section{ADDRESS FOR CORRESPONDENCE:}

Magdalena M. Panek, Department of Mother and Child Health, Institute of Nursing and Midwifery, Jagiellonian

University Medical College, 25 Kopernika St., 31-501 Krakow, Poland, ORCID: 0000-0002-6329-3686,

e-mail: panek.magdalena.mp@gmail.com 
ing patients to suffering. An important problem is also pain assessment using existing pain scales. Although it should be performed in all newborns, very often practices are based on doctors' own experience, and not on reliable tools for pain assessment. Although the approach to neonatal pain management has changed in the last forty years, pain treatment in this group is still insufficient [1-3].

For newborns, the 1980s brought improvements in the prevention and treatment of pain. Reports began to appear, indicating the consequences of untreated pain in this group. In 1981, Robinson and Gregory were among the first to provide evidence that newborns born before 37 completed weeks of gestation tolerate anaesthesia well [4]. Nowadays, we know that newborns born prematurely may show even greater sensitivity to pain than full-term babies. Furthermore, the enormous progress that has been made in neonatology is associated with an increasing number of painful or stressful procedures performed in newborns. Studies show that the number of painful procedures per newborn staying in an intensive care unit varies from 12 to 16 in one day. In extreme situations, up to 62 procedures may occur daily [5].

In the pain management of newborns, it can be seen that the multidimensional approach proposed by John Bonica is very useful. He did not believe in a single special drug that would help to completely relieve pain. He pointed out that only cooperation between many specialists can contribute to alleviate pain. According to this knowledge, collaboration between nurses and physicians could play a key role in pain management [6]. Additionally, it is also important to combine nonpharmacological and pharmacological methods of pain relief. Although the mechanism of action of non-pharmacological methods is not fully understood, the combination of both methods can lead to a holistic approach to pain treatment. One of the benefits of using non-pharmacological methods is to divert the attention of the newborn and reduce the level of stress, which emphasises the emotional dimension of pain. Reports show that excessive stress is harmful to the child's brain because it is associated with the release of excessive amounts of cortisol [7]. The multidimensional approach to pain treatment in newborns can be illustrated as a six-step approach. Pain management in neonates should begin with the avoidance of painful procedures as much as possible, then it should be followed by nonpharmacological and pharmacological methods for pain relief. Several books and articles regarding neonatal pain management have been published, and it has become evident that neonatal pain must be treated [8].

The aim of the study was to assess the knowledge of the basic issues related to pain in newborns, as well as to describe practices for pain management and assessment in Polish neonatal units.

\section{MATERIAL AND METHODS}

An anonymous questionnaire was developed by the author. To ensure construct and face validity the questionnaire was used among a pilot study group. The survey was sent to randomly selected neonatal departments throughout Poland. The questionnaire was made up of three parts; in total it contained 40 questions. The first section asked about demographic information and basic knowledge regarding pain management. The second part asked about current practices for pain treatment before particular procedures. The third section asked about the existence of rules for pain relief, and the frequency of use of pain assessment tools. The research began in October 2014, after obtaining a positive opinion from the Bioethics Committee of the Jagiellonian University. A total of 1302 surveys were sent to 100 hospitals. All provinces took part in the survey, including 52 cities (Table 1). Statistical analyses were performed using the SPSS statistical software. The significance level was set at $p<0.5$.

TABLE 1. List of cities participating in the study

\begin{tabular}{|c|c|c|c|c|}
\hline Wrocław & Zabrze & Rzeszów & Sokołów Podlaski & Gdańsk \\
Legnica & Ruda Śląska & Brzozów & Płock \\
Jelenia Góra & Częstochowa & Tarnobrzeg & Ciechanów & Lębork \\
Wałbrzych & Cieszyn & Lublin & Siedlce & Bytów \\
Lubin & Knurów & Krosno & Ostrów Mazowiecka & Szczecin \\
Bogatynia & Tarnowskie Góry & Chełm & Łódź & Koszalin \\
Kłodzko & Gliwice & Biała Podlaska & Sieradz & Poznań \\
Bydgoszcz & Kraków & Zamość & Zgierz & Konin \\
Grudziądz & Tarnów & Włodawa & Skierniewice & Leszno \\
Toruń & Bochnia & Kielce & Białystok & Jarocino \\
Włocławek & Nowy Targ & Busko-Zdrój & Łomża & Jeżyce \\
Inowrocław & Gorlice & Końskie & Suwałki & Zielona Góra \\
Opole & Chrzanów & Włoszczowa & Bielsk Podlaski & Nowa Sól \\
Strzelce Opolskie & Nowy Sącz & Sandomierz & Elbląg & Gorzów Wielkopolski \\
Kędzierzyn-Koźle & Olkusz & Staszów & Biskupiec & Sulechów \\
Katowice & Brzesko & Warszawa & Ełk & \\
Bytom & Dąbrowa Tarnowska & & & \\
\hline
\end{tabular}


TABLE 2. Assessment of the manner of prescribing pain killers

\begin{tabular}{|l|c|c|c|c|c|c|c|}
\hline \multirow{2}{*}{ How often do you prescribe pain medicines? } & \multicolumn{2}{|c|}{$\begin{array}{c}\text { Level I } \\
\text { neonatal units }\end{array}$} & \multicolumn{2}{c|}{$\begin{array}{c}\text { Level II } \\
\text { neonatal units }\end{array}$} & \multicolumn{2}{c|}{$\begin{array}{c}\text { Level III } \\
\text { neonatal units }\end{array}$} & \multirow{2}{*}{$p^{*}$} \\
\cline { 2 - 8 } & $n$ & $\%$ & $n$ & $\%$ & $n$ & $\%$ & \\
\hline On the basis of experience & 11 & 68 & 63 & 65 & 78 & 64 & 0.003 \\
\hline Following the suggestions of nurses & 4 & 21.3 & 19 & 19.2 & 28 & 23.2 & $<0.001$ \\
\hline According to guidelines & 1 & 10.7 & 15 & 15.8 & 16 & 12.8 & 0.001 \\
\hline
\end{tabular}

${ }^{*} \chi^{2}$ test

The distributions of the analysed variables are presented as absolute and relative numbers in the case of qualitative variables. Quantitative variables are presented as the mean and standard deviation, or the median and interquartile range, depending on the compatibility of their distribution with normal distribution. A $\chi^{2}$ test was used to examine the relationship between qualitative variables. Three or more groups of variables were compared using the Kruskal-Wallis test. The comparison of the self-assessment of pain treatment according to the guidelines was assessed using McNemar's test. We also used Spearman rank correlations to investigate the relationship between two quantitative variables.

\section{RESULTS}

Among physicians, most respondents worked in level III (122/235) and level II (97/235) hospitals. Only 16 respondents worked in level I hospitals. A total of 142 respondents $(60.43 \%)$ had completed a specialisation in neonatology. Sixty-two respondents (26.38\%) did not have specialisation, and $31(13.19 \%)$ were in the process of specialisation. 167 (71\%) had more than 16 years' experience in neonatology, 33 respondents (14.04\%) had 6-15 years', and 30 respondents (12.77\%) had from 13 months' to 5 years' experience. Only five respondents had been working for less than 12 months (2.13\%).

\section{PAIN TREATMENT ACCORDING TO THE GUIDELINES}

Most neonatal units do not have guidelines for the treatment of pain in newborns. 152 doctors relied on their own experience during pain treatment. Only thirty-two of them followed the guidelines. There was also a group of physicians (51) who ordered pain treatment under the influence of a nurse's or midwife's suggestion (Table 2).

Moreover, the study also revealed that pain treatment before selected painful diagnostic-therapeutic procedures did not follow guidelines. The obtained answers were related to the pattern adopted by the authors, i.e. the guidelines for analgesic treatment of the American and Canadian Pediatric Societies, published in 2006. Among the doctors, the median proportion of correct answers was $25 \%\left(Q_{1}=0 \%, Q_{3}=50 \%\right)$. Further investigation of the effect of different factors showed there was no significant

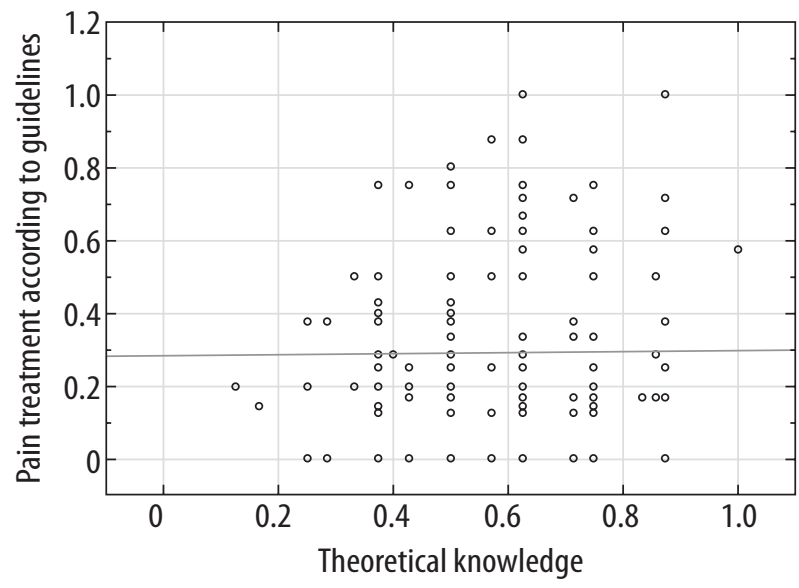

FIGURE 1. Distribution of procedures according to guidelines in relation to theoretical knowledge $(r=-0.04, p=0.6)$

correlation between the theoretical knowledge of doctors and pain treatment in accordance with the guidelines $(r=-0.04, p=0.6)$ (Fig. 1).

For instance, before chest tube insertion level II units were more likely to administer midazolam before the procedure. More than half of the participants (56.7\%) responded to this answer. Thirty-four doctors prescribed paracetamol before this procedure (compared with 54 who very often used opioids). As many as $12 \%$ of respondents from level III units reported that they very often or often used non-pharmacological methods of pain relief (glucose) (Table 3).

Before central venous catheter insertion $70 \%$ of doctors from level II units and 42\% from level III units very often or often administered paracetamol (Table 4).

Before lumbar puncture about $66.6 \%$ of respondents from level I neonatal units reported that they asked nurses to give the child glucose/sucrose. $49.9 \%$ ordered the use of Emla cream. Among the surveyed physicians from level II neonatal units, $36.8 \%$ ordered glucose, $27 \%$ asked Perfalgan, and $32.1 \%$ midazolam. Emla cream was used by $10 \%$ of respondents. In level III NICUs, a quarter of doctors very often or often did not commission anything before performing the procedure. Emla cream (43.2\%), paracetamol (38.1\%), and glucose (36.4\%) were the most commonly prescribed drugs (Table 5).

On average, $70 \%$ of the physicians did not order a painkiller before endotracheal tube suction (Table 6). 
TABLE 3. Frequency of use of medicines before chest tube insertion

\begin{tabular}{|l|c|c|c|c|c|}
\hline \multirow{2}{*}{$\begin{array}{l}\text { Before chest tube } \\
\text { insertion, } \\
\text { what do you order? }\end{array}$} & \multicolumn{2}{|c|}{$\begin{array}{c}\text { Level II } \\
\text { neonatal units } \\
n=62\end{array}$} & \multicolumn{2}{c|}{$\begin{array}{c}\text { Level III } \\
\text { neonatal units } \\
n=115\end{array}$} & $p^{*}$ \\
\cline { 2 - 6 } & Very often, often (\%) & Never, rarely (\%) & Very often, often (\%) & Never, rarely (\%) \\
\hline Nothing & 6.4 & 93.6 & 4.3 & 95.7 & 0.73 \\
\hline Midazolam & 30.6 & 69.4 & 25.2 & $74.8^{*}$ & 0.63 \\
\hline 1 dose of opioid & 53.5 & 46.5 & 81.6 & 18.4 & $<0.001$ \\
\hline Glucose/sucrose & 11.2 & 88.8 & 11.3 & 88.7 & 0.55 \\
\hline Paracetamol & 12.9 & 87.1 & 22.6 & 77.4 & 0.001 \\
\hline Ketamine & 0 & 100 & 15.6 & 84.4 & 0.001 \\
\hline 1\% lidocaine s.c. & 49.9 & 50.1 & 41.8 & 58.2 & 0.72 \\
\hline
\end{tabular}

TABLE 4. Frequency of use of selected drugs before central line insertion

\begin{tabular}{|l|c|c|c|c|c|}
\hline \multirow{2}{*}{$\begin{array}{l}\text { Before CvC insertion, } \\
\text { What do you order? }\end{array}$} & \multicolumn{2}{|c|}{$\begin{array}{c}\text { Level II } \\
\text { neonatal units } \\
n=51\end{array}$} & \multicolumn{2}{c|}{$\begin{array}{c}\text { Level III } \\
\text { neonatal units } \\
n=112\end{array}$} & $p^{*}$ \\
\cline { 2 - 6 } & Very often, often (\%) & Never, rarely (\%) & Very often, often (\%) & Never, rarely (\%) \\
\hline Nothing & 17.7 & 82.3 & 21.4 & 78.6 & 0.13 \\
\hline Opioids & 5.9 & 94.1 & 31.2 & 68.8 & 0.001 \\
\hline Midazolam & 37.2 & 62.8 & 25.2 & 75 & 0.513 \\
\hline Phenobarbital & 33.3 & 66.7 & 26.7 & 73.3 & 0.73 \\
\hline Paracetamol & 70.6 & 29.4 & 42.8 & 57.2 & $<0.001$ \\
\hline Ketamine & 7.9 & 92.1 & 18.7 & 67.3 & 0.024 \\
\hline Glucose/sucrose & 24.4 & 75.6 & 32.1 & 6.9 & 0.17 \\
\hline
\end{tabular}

TABLE 5. Frequency of use of selected drugs before lumbar puncture

\begin{tabular}{|c|c|c|c|c|c|c|c|}
\hline \multirow[t]{2}{*}{$\begin{array}{l}\text { Before lumbar } \\
\text { puncture, } \\
\text { what do you order? }\end{array}$} & \multicolumn{2}{|c|}{$\begin{array}{l}\text { Level I } \\
\text { neonatal units } \\
n=6\end{array}$} & \multicolumn{2}{|c|}{$\begin{array}{c}\text { Level II } \\
\text { neonatal units } \\
n=87\end{array}$} & \multicolumn{2}{|c|}{$\begin{array}{c}\text { Level III } \\
\text { neonatal units } \\
n=118\end{array}$} & \multirow[t]{2}{*}{$p^{*}$} \\
\hline & $\begin{array}{c}\text { Very often, } \\
\text { often }(\%)\end{array}$ & $\begin{array}{c}\text { Never, } \\
\text { rarely (\%) }\end{array}$ & $\begin{array}{l}\text { Very often, } \\
\text { often (\%) }\end{array}$ & $\begin{array}{c}\text { Never, } \\
\text { rarely (\%) }\end{array}$ & $\begin{array}{c}\text { Very often, } \\
\text { often (\%) }\end{array}$ & $\begin{array}{c}\text { Never, } \\
\text { rarely (\%) }\end{array}$ & \\
\hline Nothing & 0 & 100 & 14.9 & 85.1 & 25.4 & 74.6 & 0.36 \\
\hline Local anaesthetics (EMLA) & 49.9 & 50.1 & 10.3 & 89.7 & 43.2 & 56.8 & $<0.001$ \\
\hline Glucose/sucrose & 66.6 & 33.4 & 36.8 & 63.2 & 36.4 & 63.6 & 0.349 \\
\hline Paracetamol & 0 & 100 & 27 & 73 & 38.1 & 61.9 & 0.017 \\
\hline Opioids & 0 & 100 & 10.3 & 89.7 & 18.6 & 81.4 & 0.001 \\
\hline Midazolam & 16.6 & 83.4 & 32.1 & 67.9 & 22 & 78 & 0.359 \\
\hline
\end{tabular}

${ }^{*}$ Kruskal-Wallis test

\section{DRUGS USE}

Phenobarbital intravenous/per os/per rectum was the most frequently used drug (76\% of respondents from level III NICUs), followed by midazolam (75\% of respon- dents from level III NICUs). The percentage of selected medicines that were ordered varied, and the frequency depended on the degree of level of the neonatal unit. A higher degree was associated with more frequent use of all these drugs (Table 7). 
TABLE 6. Frequency of use of selected drugs before endotracheal tube suction

\begin{tabular}{|l|c|c|c|c|c|c|c|}
\hline \multirow{2}{*}{$\begin{array}{l}\text { Before endotracheal } \\
\text { tube suction }\end{array}$} & \multicolumn{2}{|c|}{$\begin{array}{c}\text { Level I } \\
\text { neonatal units } \\
n=5\end{array}$} & \multicolumn{2}{c|}{$\begin{array}{c}\text { Level II } \\
\text { neonatal units } \\
n=78\end{array}$} & \multicolumn{2}{c|}{$\begin{array}{c}\text { Level III } \\
\text { neonatal units } \\
n=115\end{array}$} & $p^{*}$ \\
\cline { 2 - 9 } & $\begin{array}{c}\text { Very often, } \\
\text { often (\%) }\end{array}$ & $\begin{array}{r}\text { Never, } \\
\text { rarely (\%) }\end{array}$ & $\begin{array}{c}\text { Very often, } \\
\text { often (\%) }\end{array}$ & $\begin{array}{r}\text { Never, } \\
\text { rarely (\%) }\end{array}$ & $\begin{array}{c}\text { Very often, } \\
\text { often (\%) }\end{array}$ & $\begin{array}{c}\text { Never, } \\
\text { rarely (\%) }\end{array}$ & \\
\hline Nothing & 40 & 60 & 66.6 & 33.4 & 73 & 27 & 0.39 \\
\hline Midazolam & 0 & 100 & 9 & 91 & 9.6 & 90.4 & 0.09 \\
\hline Paracetamol & 0 & 100 & 2.6 & 97.4 & 10.4 & 89.6 & $<0.001$ \\
\hline Opioids & 0 & 100 & 1.3 & 98.7 & 12.1 & 97.9 & 0.006 \\
\hline
\end{tabular}

*Kruskal-Wallis test

TABLE 7. Frequency of use of selected drugs in Polish NICUs

\begin{tabular}{|c|c|c|c|c|c|c|c|}
\hline \multirow[t]{2}{*}{ Drugs } & \multicolumn{2}{|c|}{$\begin{array}{c}\text { Level I } \\
\text { neonatal units } \\
n=13\end{array}$} & \multicolumn{2}{|c|}{$\begin{array}{c}\text { Level II } \\
\text { neonatal units } \\
n=96\end{array}$} & \multicolumn{2}{|c|}{$\begin{array}{c}\text { Level III } \\
\text { neonatal units } \\
n=118\end{array}$} & \multirow[t]{2}{*}{$p^{*}$} \\
\hline & $\begin{array}{c}\text { Very often, } \\
\text { often (\%) }\end{array}$ & $\begin{array}{l}\text { Never, } \\
\text { rarely }(\%) \\
\end{array}$ & $\begin{array}{c}\text { Very often, } \\
\text { often (\%) }\end{array}$ & $\begin{array}{c}\text { Never, } \\
\text { rarely (\%) }\end{array}$ & $\begin{array}{c}\text { Very often, } \\
\text { often (\%) }\end{array}$ & $\begin{array}{c}\text { Never, } \\
\text { rarely }(\%) \\
\end{array}$ & \\
\hline Phenobarbital IV & 7.7 & 92.3 & 51 & 49 & 76.2 & 23.8 & $<0.001$ \\
\hline $\begin{array}{l}\text { Phenobarbital } \\
\text { per os/per rectum }\end{array}$ & 7.7 & 92.3 & 53.1 & 46.9 & 75.4 & 24.6 & $<0.001$ \\
\hline Midazolam & 0 & 100 & 36.4 & 63.6 & 75.1 & 24.9 & $<0.001$ \\
\hline Paracetamol & 7.7 & 92.3 & 30.2 & 69.8 & 43.2 & 56.8 & $<0.001$ \\
\hline Opioids & 0 & 100 & 13.5 & 86.5 & 81.3 & 18.7 & $<0.001$ \\
\hline Thiopental & 0 & 100 & 1 & 99 & 64.4 & 35.6 & $<0.001$ \\
\hline Ketamine & 0 & 100 & 2.1 & 97.9 & 18.6 & 81.4 & $<0.001$ \\
\hline Muscle relaxant & 0 & 100 & 6 & 94 & 41 & 59 & 0.014 \\
\hline
\end{tabular}

*Kruskal-Wallis test

TABLE 8. Frequency of use of selected drugs for mechanical ventilates neonates

\begin{tabular}{|l|c|c|c|c|c|c|c|}
\hline $\begin{array}{l}\text { Medicines given } \\
\text { for mechanically } \\
\text { ventilated babies }\end{array}$ & \multicolumn{2}{c|}{$\begin{array}{c}\text { Level I } \\
\text { neonatal units } \\
n=32\end{array}$} & \multicolumn{2}{c|}{$\begin{array}{c}\text { Level II } \\
\text { neonatal units } \\
n=85\end{array}$} & \multicolumn{2}{c|}{$\begin{array}{c}\text { Level III } \\
\text { neonatal units } \\
n=337\end{array}$} & $p^{*}$ \\
\cline { 2 - 9 } & $\begin{array}{c}\text { Very often, } \\
\text { often (\%) }\end{array}$ & $\begin{array}{c}\text { Never, } \\
\text { rarely (\%) }\end{array}$ & $\begin{array}{c}\text { Very often, } \\
\text { often (\%) }\end{array}$ & $\begin{array}{c}\text { Never, } \\
\text { rarely (\%) }\end{array}$ & $\begin{array}{c}\text { Very often, } \\
\text { often (\%) }\end{array}$ & $\begin{array}{c}\text { Never, } \\
\text { rarely (\%) }\end{array}$ & \\
\hline Opioids & 0 & 100 & 21 & 79 & 51 & 49 & $<0.001$ \\
\hline Midazolam & 0 & 100 & 45 & 55 & 39 & 61 & 0.001 \\
\hline Phenobarbital IV & 20 & 80 & 56 & 44 & 63 & 37 & 0.027 \\
\hline Thiopental & 0 & 100 & 2 & 98 & 3 & 97 & 0.001 \\
\hline Muscle relaxant & 0 & 100 & 0 & 100 & 0 & 100 & 0.046 \\
\hline Ketamine & 0 & 100 & 2 & 98 & 8 & 92 & 0.016 \\
\hline Nothing & 80 & 20 & 9 & 91 & 11 & 89 & 0.763 \\
\hline
\end{tabular}

* Kruskal-Wallis test

Sixty-one per cent of physicians from level III NICUs reported that phenobarbital was very often or often used for babies who needed mechanical ventilation, compared to $51 \%$ of physicians who chose very often or often to use opioids (Table 8).

\section{SELF-EVALUATION OF PAIN MANAGEMENT}

Self-assessment regarding pain treatment indicated that 129 doctors believed that their method of pain treatment was sufficient (Fig. 2). 


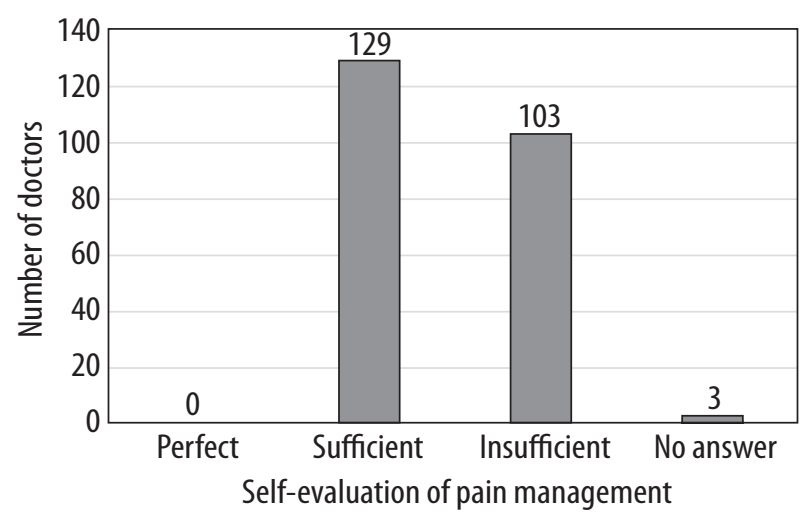

FIGURE 2. Self-evaluation of pain management

TABLE 9. The relationship between self-esteem and pain treatment according to the guidelines

\begin{tabular}{|l|c|c|c|}
\hline \multirow{2}{*}{$\begin{array}{l}\text { Studied } \\
\text { factors }\end{array}$} & \multicolumn{3}{|c|}{$\begin{array}{c}\text { Pain treatment according } \\
\text { to the guidelines }\end{array}$} \\
\cline { 2 - 3 } & Sufficient & Insufficient & \multirow{2}{*}{$p^{*}$} \\
\hline Self-evaluation & $n(\%)$ & $n(\%)$ & $<0.001$ \\
\hline Sufficient & $23(10.79)$ & $14(6.51)$ & \\
\hline Insufficient & $96(44.56)$ & $82(38.14)$ & \\
\hline *McNemar'stest & & & \\
\hline
\end{tabular}

In order to compare pairs of answers regarding selfassessment of doctors' own analgesia and the pain treatment according to the guidelines, the McNemary test was used. The analysis shows that 14 people considered their approach to treating pain to be sufficient, although they did not follow the accepted rules (Table 9).

\section{DISCUSSION}

This is the first study to examine pain management in Polish neonatal units. This survey showed that procedural pain was still undertreated and underscored. Head neonatologists could have participated in this study, but the target group was the staff who work with patients on a daily basis. Japanese researchers in their work have paid attention to this problem. They admitted that the results of research obtained only from the people directing the work of the ward may not reflect the real situation in the ward and might be based only on their imagination and opinions on current practices [9].

The data regarding the characteristics of the study group showed that the majority of physicians participating in the study had worked in the profession for more than 16 years. Therefore, efforts should also aim at ensuring that people with the longest experience properly manage pain in newborns; thanks to this, they could be an example and could teach younger doctors correct analgesia methods. One hundred study participants from Jamaica admitted that they rarely ordered analgesia before the treatments that were previously described as painful by them. Respondents explained the lack of analgesia by the fact that the duration of the painful procedure is very short, and therefore it does not require analgesia $[8,10]$.

In this study it was observed that about $60 \%$ of physicians based their pain management on their own experience. Individual physicians' abilities and experience are irreplaceable when making a diagnosis and choosing a therapeutic procedure. However, knowledge of scientific research data is necessary when considering the beneficial and adverse effects of diagnostic and therapeutic activities. Our research also showed that according to the guidelines, analgesics were ordered only by about $13 \%$ of doctors. The lack of written guidelines in neonatal wards has been demonstrated in many studies. In Japan, documents that mentioned analgesia were available in $14.5 \%$ of centres (in the opinion of head nurses) and in 20.4\% of centres in the opinion of head neonatologists [9]. In Australia, only 76 out of 215 centres had written guidelines for the treatment of pain, while in Spain there were 13 units out of a total of 30 [11, 12].

Even though effective pain management in neonates has been shown to reduce mortality and morbidity, this study showed that a large proportion of respondents did not use analgesics. In one of the first studies on the treatment of pain in newborns it was shown that only 11 anaesthesiologists used opioid analgesics, compared to 98 in 1995. In studies from 2006 regarding post-operative pain management in newborns, it was pointed out that opioid analgesics were used in $84 \%$ of major surgical procedures [13]. This study showed that before inserting a drain into the pleural cavity, five out of 115 doctors from level III NICUs did not order anything. In addition, collected data indicated the frequent use of paracetamol in order to prevent procedural acute pain. According to recommendations, the most common indication for the intravenous use of this drug is the short-term treatment of moderate pain, especially in the postoperative period. According to the WHO Pain Relief Ladder, paracetamol is the medicine of choice in the first step when mild pain occurs. If pain severity is assessed as moderate or severe, the administration of a strong opioid is necessary [14].

Further proof of abnormal treatment of pain in newborns is the fact that paracetamol was ordered before central venous catheter insertion (paracetamol 84 respondents, opioid analgesics 38 respondents, sweet solutions 47 respondents). There are studies confirming the correctness of using sweet solutions before the discussed procedure. In addition, the recommendations indicate the possibility of using opioid analgesics in exceptional situations, but not paracetamol [15]. Another procedure before which the use of analgesia raises a lot of controversy is pain treatment before tracheal suction among intubated newborns. Literature sources indicate that in neonatal wards this procedure was performed 9883 times during the first 14 days in 430 newborns, which gives a total of 23 procedures per patient [16]. It should be emphasised that studies carried out in an adult group, conscious but 
intubated, staying in intensive care units show that the endotracheal tube suction procedure is associated with moderate to severe pain [17]. Our results indicate that 84 physicians working in level III NICUs did not order any drugs before this procedure.

The study also found that the frequency of use of opioid analgesics, midazolam or Perfalgan, was similar. One of the reasons why painkillers were not given was the fact that the newborn received painkillers by continuous infusion. However, as research shows, the use of analgesics via continuous infusion does not prevent the child from experiencing painful procedures $[18,19]$.

In addition, in this study the use of opioids for ventilated newborns was observed (Table 7). Despite the widespread use of opioids, there are still insufficient arguments to recommend routine administration in mechanically ventilated newborns, even if this procedure is undeniably associated with pain $[20,21]$. Authors of studies on the use of opioids during mechanical ventilation focus primarily on the direct impact of the drugs used on the central nervous system, the duration of mechanical ventilation, and the possibility of including enteral nutrition. Studies show that in this group of patients the use of opioids does not affect their survival, intracavernous or periventricular leukomalacia, or duration of mechanical ventilation. Interestingly, the use of morphine may be associated with a longer mechanical ventilation time and difficulties in achieving full enteral nutrition [22]. Current guidelines do not support the use of midazolam in neonates. It has been claimed that sedation may instead mask the pain response in neonates. It is therefore concerning that in level II neonatal units sedation drugs were more often used than analgesics. Further analysis showed that the most commonly administered drugs were opioids, phenobarbital, midazolam, and thiopental. Particularly alarming are the results of a similar frequency of analgesics (109 doctors very often used opioid analgesics) and midazolam (124 respondents).

The weakness of the research may additionally be a disproportion in the selection of the reference level of centres (too few centres of the first degree). The number of surveys that can be analysed (852) can be considered as a strength of the study, as well as the fact that the survey covered the whole of Poland with a large representation of centres of the second and third degrees of reference. Thanks to that, as a result of very reliable statistical analysis, we managed to get enough information to infer about the practice of pain treatment.

\section{CONCLUSIONS}

In Poland during the analysed period pain treatment in neonates was insufficient and did not comply with standards.

The lack of appropriate pharmacological and non-pharmacological treatment and use of pain scales is a signif- icant problem, especially in the group of patients most dependent on medical staff.

Despite the great change that has taken place in the treatment of pain in newborns, there is still concern about insufficient pain management among physicians and nurses.

\section{DISCLOSURE}

The authors declare no conflict of interest.

\section{REFERENCES}

1. Meek J. Options for procedural pain in newborn infants. Arch Dis Child Educ Pract Ed 2012; 97: 23-28.

2. Lago P, Garetti E, Merazzi D, et al. Guidelines for procedural pain in the newborn. Acta Paediatrica 2009; 98: 932-939.

3. American Academy of Pediatrics Committee on Fetus and Newborn, American Academy of Pediatrics Section on Surgery, Canadian Paediatric Society Fetus and Newborn Committee, et al. Prevention and management of pain in the neonate: an update. Pediatrics 2006; 116: 2231.

4. Robinson S, Gregory GA. Fentanyl-air-oxygen anesthesia for ligation of patent ductus arteriosus in preterm infants. Anesth Analg 1981; 60: 331-334.

5. Carbajal R, Rousset A, Danan C, et al. Epidemiology and treatment of painful procedures in neonates in intensive care units. JAMA 2008; 300: 60-70.

6. Bonica JJ. History of pain concepts and therapies. In: The management of pain. 2nd ed. Lea and Febiger, Philadelphia, London 1990; 2-17.

7. Lago P, Garetti E, Pirelli A, et al. Non-pharmacological intervention for neonatal pain control. Ital J Pediatr 2014; 40 (Suppl 2): A52.

8. Wilson-Smith EM. Procedural pain management in neonates, infants and children. Rev Pain 2011; 5: 4-12.

9. Ozawa M, Yokoo K. Pain management of neonatal intensive care units in Japan. Acta Paediatr 2013; 102: 366-372.

10. Lago P, Garetti E, Merazzi D, et al. Pain Study Group of the Italian Society of Neonatology. Guidelines for procedural pain in the newborn. Acta Paediatr 2009; 98: 932-939.

11. Foster J, Spence K, Henderson-Smart D, et al. Procedural pain in neonates in Australian hospitals: a survey update of practices. J Paediatr Child Health 2013; 49: 35-39.

12. Avila-Alvarez A, Carbajal R, Courtois E, et al. Valoración clínica del dolor en unidades de cuidados intensivos neonatales españolas. An Pediatr (Barc) 2016; 85: 181-188.

13. de Lima J, Lloyd-Thomas AR, Howard RF, et al. Infant and neonatal pain: anaesthetists' perceptions and prescribing patterns. BMJ 1996; 313: 787.

14. World Health Organization. WHO guidelines on the pharmacological treatment of persisting pain in children with medical illnesses, 2012 (access: 20.02.2017). http://apps.who.int/iris/bitstr eam/10665/44540/1/9789241548120_Guidelines.pdf

15. Lago P, Garetti E, Merazzi D, et al. Pain Study Group of the Italian Society of Neonatology. Guidelines for procedural pain in the newborn. Acta Paediatr 2009; 98: 932-939.

16. Cruz MD, Fernandes AM, Oliveira CR. Epidemiology of painful procedures performed in neonates: A systematic review of observational studies. Eur J Pain 2016; 20: 489-498.

17. Arroyo-Novoa CM, Figueroa-Ramos MI, Puntillo KA, et al. Pain related to tracheal suctioning in awake acutely and critically ill adults: a descriptive study. Intensive Crit Care Nurs 2008; 24: 20-27. 
18. Slater R, Cantarella L, Franck, et al. How well do clinical pain assessment tools reflect pain in infants? PLoS Med 2008; 5: e129.

19. Karpe J, Misiołek A, Daszkiewicz A, Misiołek H. Obiektywna ocena stresu bólowego u noworodków wentylowanych mechanicznie mierzonego metodą zmiany przewodnictwa skórnego. Anest Intens Ter 2013; 45: 141-145.

20. Bellu R, de Waal KA, Zanini R. Opioids for neonates receiving mechanical ventilation: a systematic review and meta-analysis. Arch Dis Child Fetal Neonatal Ed 2010; 95: 241-251.

21. McPherson C. Sedation and analgesia in mechanically ventilated preterm neonates: continue standard of care or experiment? J Pediatr Pharmacol Ther 2012; 17: 351-364.

22. Simons NH, van Dijk M, van Lingen RA, et al. Routine morphine infusion in preterm newborns who received ventilator support: a randomized controlled trial. JAMA 2003; 290: 2419-2427. 